\title{
PENGEMBANGAN KAMUS BERBASIS SISTEM OPERASI TELEPON PINTAR PADA MATERI BIOLOGI SMA KELAS XI
}

\author{
Rahman Fadli ${ }^{1}$, Nurmasari Sartono ${ }^{2}$, Ade Suryanda ${ }^{2}$ \\ ${ }^{1}$ Pascasarjana Pendidikan Biologi Universitas Negeri Malang, Jl. Semarang No. 5, \\ Malang, Jawa Timur \\ ${ }^{2}$ Pendidikan Biologi Universitas Negeri Jakarta, Jl. Pemuda No. 10, Jakarta \\ Timur. \\ E-mail: cerdasbermanfaat@yahoo.com
}

\begin{abstract}
The aim of this study is to produce dictionary based on smartphone operating system in Biology material class XI in Senior High School. The method of research and development adapted from Borg and Gall model. The results of the assessment needed could be concluded that students supported the dictionary based on smartphone operating system's development. Subject expert, media, and linguist score were 82,33\%; 82,85\%; and 80\%. The average trial test result to students was $76,70 \%$ and to Biology teacher was $82,75 \%$. The conclusion is the biology dictionary has very good interpretation level.
\end{abstract}

Keywords: biology dictionary, smartphone, Biology material class $X I$

Telepon pintar adalah teknologi baru yang menyerupai Personal Digital Assistant (PDA) yang memiliki berbagai fungsi dan kemudahan dalam mengakses internet (Phillippi \& Wyatt, 2011). Telepon pintar diciptakan untuk menyediakan berbagai aplikasi yang dapat diunduh dari internet dengan menggunakan sebuah sistem operasi (Cummiskey, 2011). Sistem operasi didefinisikan sebagai sebuah program yang mengatur perangkat keras komputer, dengan menyediakan landasan untuk aplikasi yang berada diatasnya, serta bertindak sebagai penghubung antara para pengguna dengan perangkat keras. Sistem operasi bertugas untuk

mengendalikan serta mengkoordinasikan pengunaan perangkat keras untuk berbagai program aplikasi (Silberschatz, et al., 2005) serta terdiri dari beberapa jenis.

Jenis-jenis sistem operasi di antaranya: Apple dengan iOS, Microsoft Windows Mobile dan Windows Phone, Nokia Symbian, RIM BlackBerry OS dan Google Android (Cummiskey, 2011). Sistem operasi Android adalah sebuah sistem operasi untuk perangkat mobile berbasis linux yang mencakup sistem operasi, middleware, dan aplikasi. Perkembangan sistem operasi Android ini yang sekarang menjadi sangat popular karena bersifat open 
soure menjadikannya sebagai sistem operasi yang banyak diminati oleh banyak pengguna (Safaat, 2011; Nielsen, 2012; Gartner, 2013).

Penggunaan aplikasi telepon pintar saat ini menyentuh beberapa lapisan masyarakat, termasuk para pelajar. Penggunaan telepon pintar sangat pesat pada berbagai kalangan, termasuk para siswa. Hal ini juga dikuatkan dengan data dari hasil analisis kebutuhan yang dilakukan pada siswa SMA Labschool Jakarta bahwa $100 \%$ siswa di sekolah tersebut telah menggunakan telepon pintar. Penggunaan telepon pintar sebagai mobile learning merupakan suatu inovasi didalam proses pembelajaran.

Mobile learning tidak dapat menggantikan pembelajaran secara tradisional namun dapat digunakan sebagai cara untuk belajar menggunakan teknologi yang inovatif (Daesang, 2013). El-Hussein (2010) menyatakan bahwa perangkat mobile canggih contohnya ponsel menawarkan fitur-fitur baru yang memberi keunggulan kompetitif bagi penggunanya. Salah satu fitur yang dapat ditawarkan adalah berbagai macam aplikasi. Aplikasi merupakan program komputer untuk membantu orang dalam suatu tugas tertentu (Nugroho, 2004). Menurut Arseno (2012) kemajuan teknologi informasi yang cepat dan progresif membuat aplikasi yang mudah dibawa dan digunakan secara efektif. Salah satu aplikasi yang dapat digunakan secara efektif adalah kamus.

Kamus merupakan salah satu jenis media visual (Sanjaya, 2011). Kamus merupakan sumber rujukan yang berisi daftar kata dengan maknanya dijelaskan atau ditulis dalam bahasa lain yang memberikan informasi mengenai makna kata, ejaan, dan ucapan yang dicari oleh pengguna (Walter dalam Lew, 2010; Kasno, 2001; Mutiawani, 2011). Secara luas diartikan sebagai daftar kata, sebagai perbendaharaan kata yang sangat luas dan tak terbatas suatu bahasa tertentu (Ratna, 2013). Kamus istilah adalah kamus yang memuat istilah dengan makna konsepnya berasal dari suatu bidang ilmu. (Harfianti, 2010). Beberapa tahun ini, kamus termasuk salah satu aplikasi populer yang sangat digemari, apalagi dengan adanya kamus elektronik berbasis sistem operasi telepon pintar (Istiqomah, 2006).

Berdasarkan analisis kebutuhan siswa di SMA Labschool Jakarta, para siswa sudah mengetahui media pembelajaran berupa kamus. Hal ini tentunya akan membantu siswa untuk menemukan istilah ilmiah atau pengertian bahasa asing di dalam Biologi dengan menggunakan kamus berbasis sistem operasi telepon pintar sebagai penunjang sumber belajar. Aplikasi kamus berbasis sistem operasi telepon pintar perlu dikembangkan agar siswa dapat memanfaatkan telepon pintar yang dimiliknya untuk proses pembelajaran. Dengan adanya kamus berbasis sistem operasi telepon pintar diharapkan siswa dapat lebih terbantukan di dalam proses pembelajaran sehingga akan mampu memotivasi siswa untuk aktif dalam belajar, dapat menambah pemahaman siswa serta mampu mengatasi kesulitannya dalam memahami istilah, bahasa ilmiah atau bahasa asing di dalam pelajaran Biologi. 


\section{METODE}

Jenis penelitian pengembangan ini mengadaptasi dari pengembangan Borg and Gall. Responden penelitian terdiri dari guru biologi dan para siswa. Teknik pengumpulan data dilakukan dengan wawancara dan pemberian angket. Wawancara dilakukan kepada guru sebagai analisis kebutuhan. Angket kuisioner digunakan untuk melakukan analisis kebutuhan terhadap 40 siswa, uji kelayakan para ahli (ahli media, ahli bahasa dan ahli materi) serta uji coba produk kelompok kecil terhadap 20 siswa dan kelompok besar terhadap 40 siswa. Teknik analisis data dilakukan secara kualitatif dan kuantitatif dengan menghitung persentase dari jawaban angket uji kelayakan para ahli (materi, bahasa dan media) serta uji coba guru biologi dan uji coba siswa.

\section{HASIL DAN PEMBAHASAN}

Hasil pengembangan kamus berbasis sistem operasi telepon pintar terdiri dari analisis kebutuhan, pengembangan produk, uji kelayakan kepada para ahli ahli, serta uji coba kepada para siswa dan guru biologi. Hasil analisis kebutuhan siswa menyatakan bahwa kamus biologi berbasis sistem operasi telepon pintar dibutuhkan oleh siswa.

Hasil pengembangan produk terdapat 1.168 daftar kata, desain rancangan kamus terdapat pada Gambar 1.

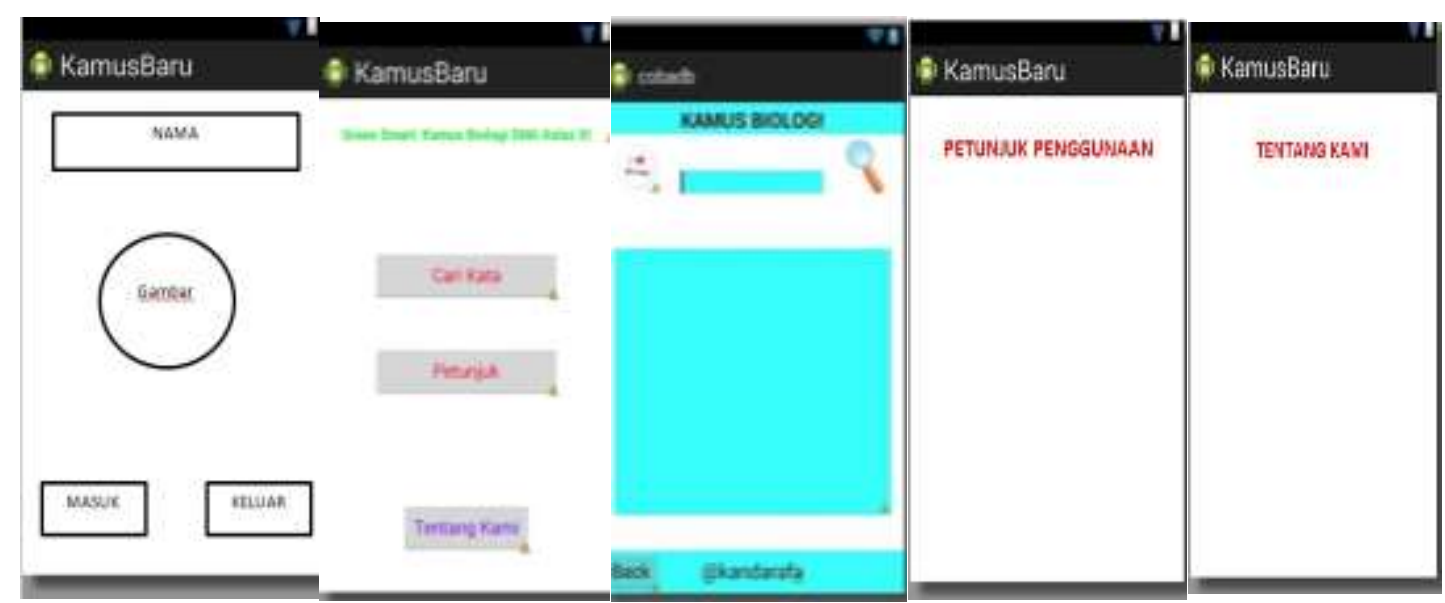

Gambar 1. Desain rancangan kamus

Setelah dilakukan perancangan, maka dilakukan tahap pengembangan produk terdiri dari penyusunan daftar kata, perancangan kamus, dan pengembangan kamus. Hasil pengembangan awal kamus dapat dilihat pada Gambar 2. 


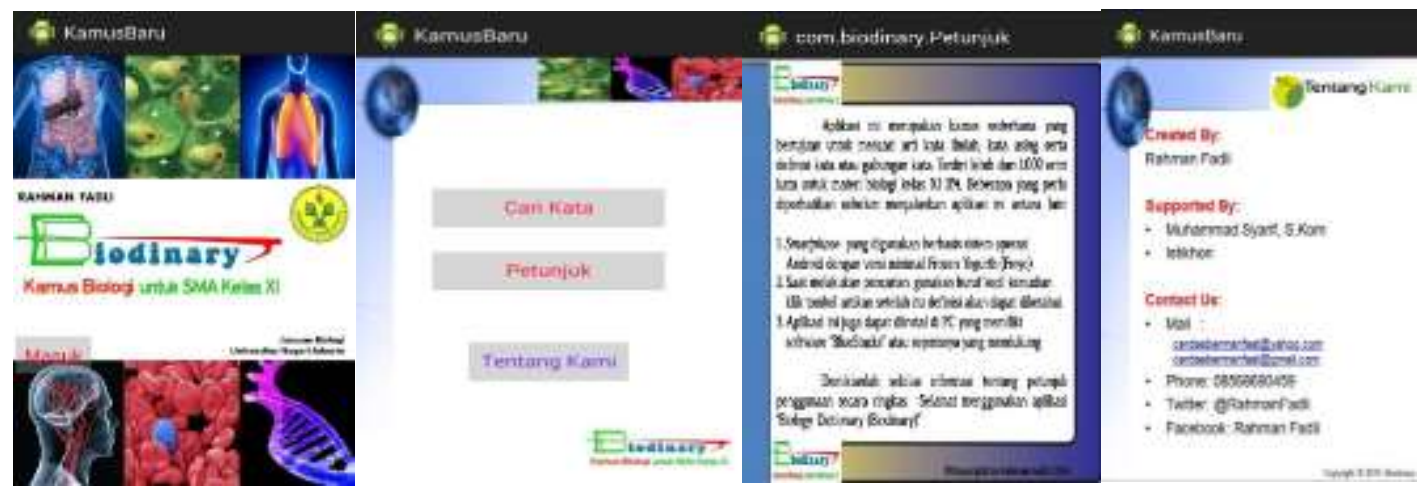

Gambar 2. Kamus biologi berbasis sistem operasi telepon pintar

Pengujian kamus berbasis sistem operasi telepon pintar kepada para ahli yang sesuai dengan bidangnya dan selanjutnya para ahli diberikan angket uji kelayakan sebagai penilaian terhadap kamus yang telah dikembangkan. Para ahli terdiri dari satu orang ahli materi, satu orang ahli bahasa, dan satu orang ahli media serta uji coba kelompok kecil. Berdasarkan data yang diperoleh dari uji kelayakan oleh ahli materi, secara keseluruhan memperoleh skor presentase $82,33 \%$ dengan interpretasi sangat baik.

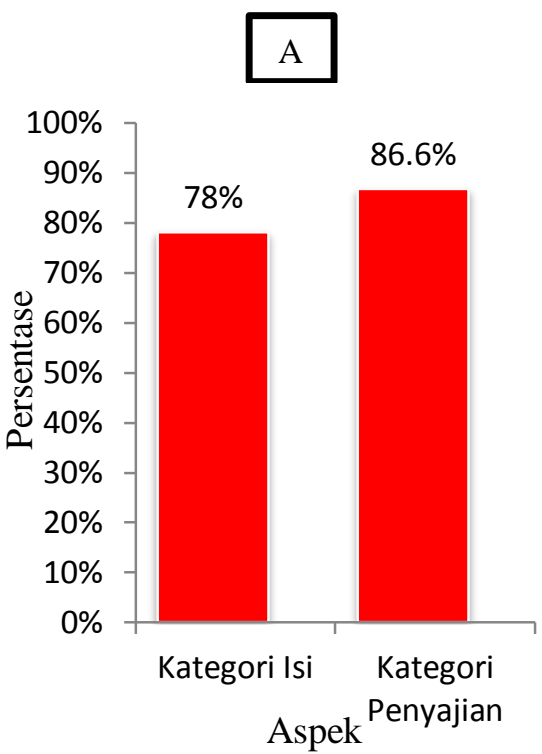

Hasil uji kelayakan oleh ahli media secara keseluruhan memperoleh skor persentase $82,85 \%$ dengan interpretasi sangat baik. Hasil uji kelayakan oleh ahli bahasa, secara keseluruhan memperoleh skor 80\% dengan interpretasi baik. Hasil uji coba kelompok kecil siswa secara keseluruhan memperoleh skor persentase rata-rata $71,04 \%$ dengan interpretasi baik. Hasil dari ahli terhadap penilaian kamus Biologi berbasis sistem operasi telepon pintar dapat dilihat pada Gambar 3.

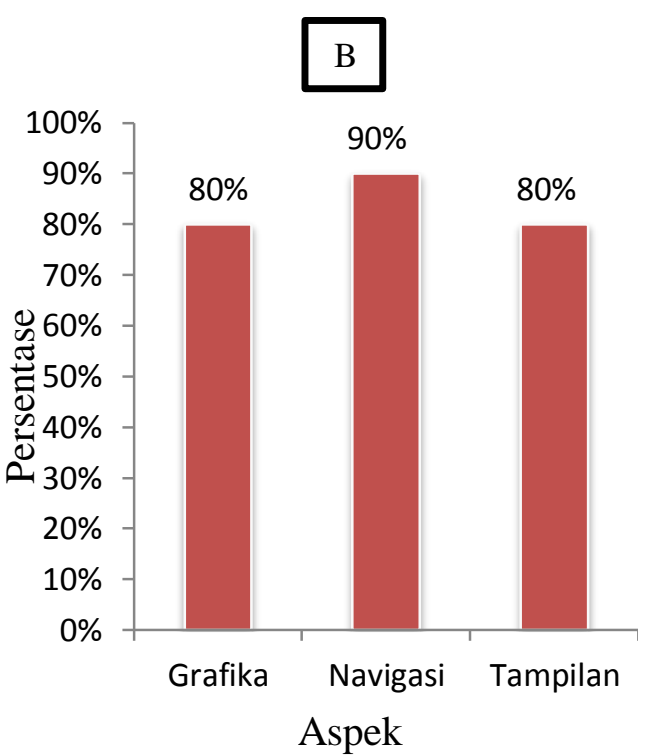




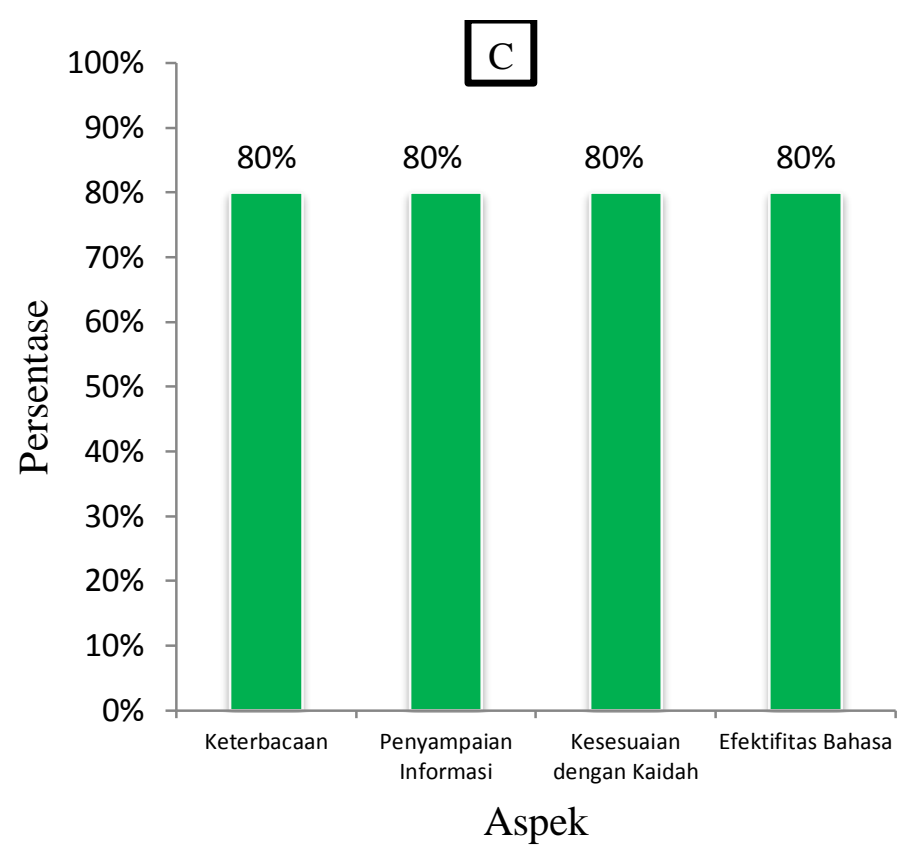

Gambar 3. Hasil uji kelayakan: (A) Materi; (B) Media; (C) Bahasa

Masukan dari ahli media digunakan untuk memperbaiki kamus dari segi tampilan dan referensi pengambilan daftar kata. Menurut Suprawoto (2009), tata letak tampilan yang baik akan menimbulkan daya tarik tersendiri terhadap minat belajar siswa. Selain itu, menurut Depdiknas (2008) media yang baik harus memperhatikan segi stimultan dan segi kemudahan dibaca. Segi stimultan menyangkut keterbacaan yang dilihat yang mendorong pembaca untuk berpikir. Segi kemudahan dibaca menyangkut keramahan terhadap mata (huruf yang digunakan tidak terlalu kecil dan mudah dibaca), uraian teks terstruktur dan mudah dibaca.

Berdasarkan masukan dan penilaian dari para ahli dan uji coba kelompok kecil, maka dilakukan perbaikan terhadap kamus. Perbaikan yang dilakukan yaitu mengubah tampilan menjadi lebih menarik dan menambahkan kolom referensi. Selain itu ahli media juga memberikan masukan untuk pengembangan jangka panjang dengan menambahkan gambar pada kamus sesuai dengan daftar kata. Hasil revisi pada kamus dapat dilihat pada Gambar 4. 


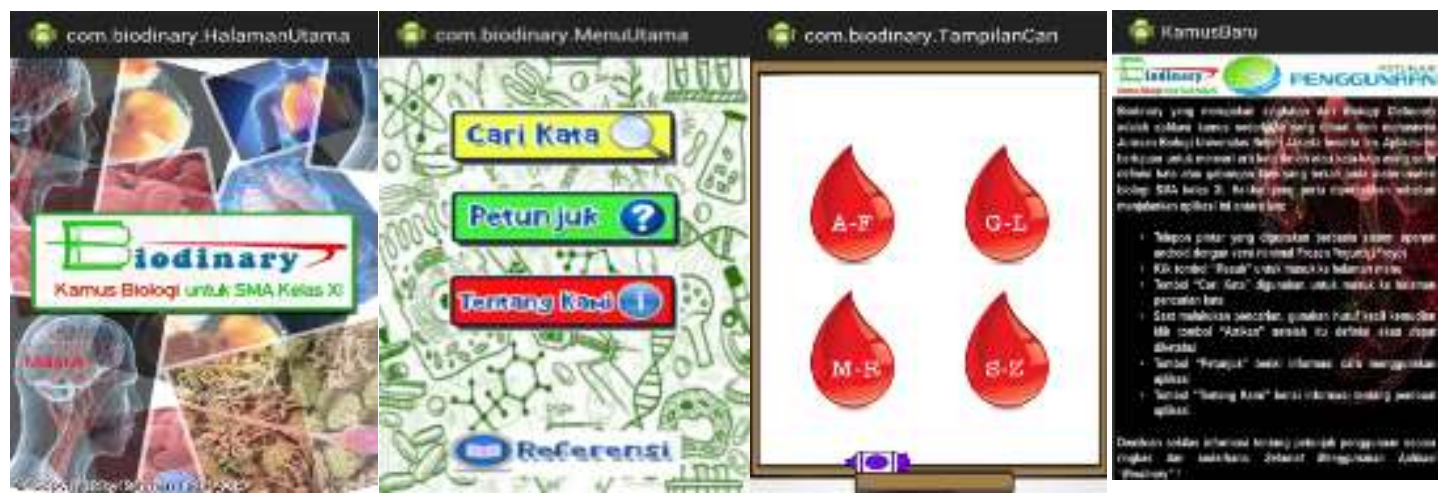

Gambar 4. Hasil revisi kamus biologi berbasis sistem operasi telepon pintar

Revisi yang dilakukan meliputi tampilan pada halaman awal, halaman menu, halaman pencaharian, dan petunjuk penggunaan. Revisi tersebut dibuat tidak kaku, sederhana, namun menarik siswa. Desain pada gambar dibuat dengan latar sistem-sistem fisiologi sebagai wujud relevansi terhadap materi kamus yang dikembangkan, yakni pada materi kelas XI yang terdiri dari sel dan

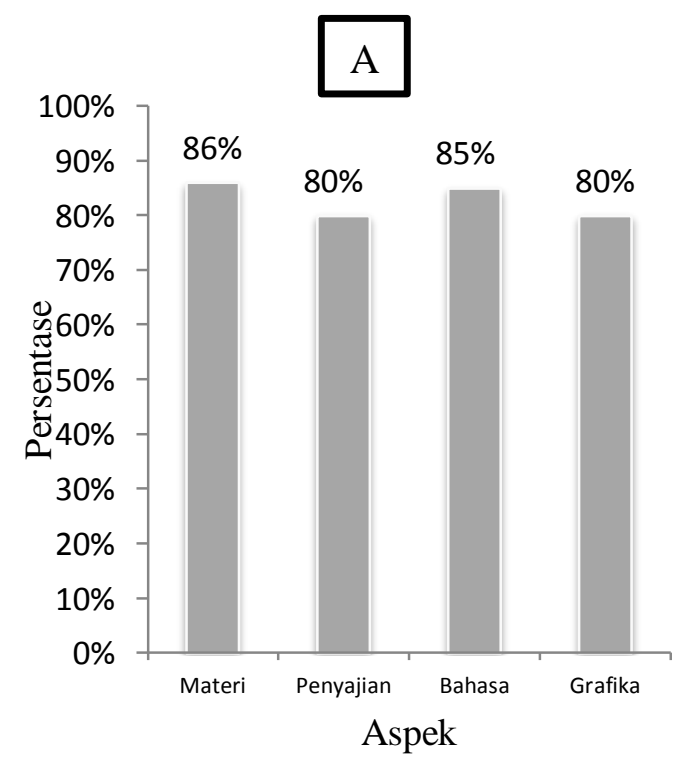

Gambar 5. Hasil Uji Kelayakan: (A) Guru; (B) Kelompok besar berbagai sistem fisiologi. Hasil revisi kemudian diujicobakan kepada guru dan siswa. Berdasarkan data yang diperoleh dari uji coba guru Biologi yang dapat dilihat pada Gambar 5, secara keseluruhan mendapatkan skor persentase rata-rata $82,75 \%$ dengan interpretasi sangat baik dan hasil uji coba kelompok besar siswa secara keseluruhan memperoleh skor persentase rata-rata $82,37 \%$ dengan interpretasi sangat baik.

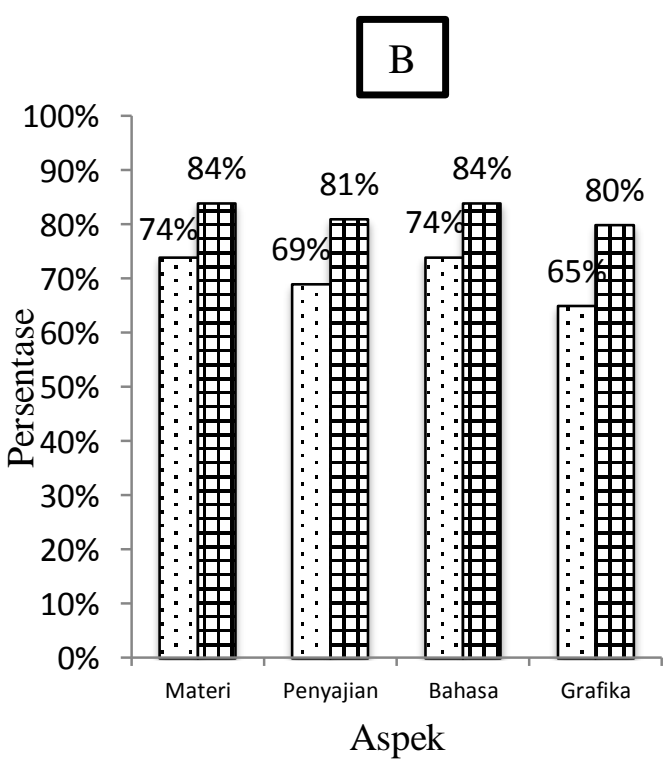

Kelompok kecil dan 曲 
Nilai kelayakan dari kamus Biologi berbasis sistem operasi telepon pintar dilakukan dengan merata-rata nilai persentase kelima uji dan penilaian. Rata-rata nilai persentase yang didapatkan adalah $80,92 \%$ dengan pembulatan $81 \%$, artinya kamus berbasis sistem operasi telepon pintar pada materi Biologi SMA kelas XI yang telah dihasilkan mendapatkan nilai dengan interpretasi sangat baik.

\section{SIMPULAN DAN SARAN}

Kamus berbasis sistem operasi telepon pintar pada materi Biologi SMA kelas XI telah dihasilkan dan mendapatkan nilai dengan interpretasi sangat baik.

Saran untuk penelitian selanjutnya diantaranya: jumlah kata di dalam kamus bisa ditambahkan; materi untuk kelas X atau XII dapat dibuat masing-masing di dalam kamus edisi selanjutnya; dapat dikembangkan di aplikasi selain basis android, misalnya IOS ataupun Windows; tampilan dan navigasi kamus dapat dibuat lebih menarik.

\section{DAFTAR PUSTAKA}

Arseno, R. (2012). Aplikasi Kamus Istilah Kedokteran Berbasis Android. Depok: Informatika Gunadarma.

Cummiskey, M. (2011). There's an App for That Smartphone Use in Health and Physical Education. Journal of Physical Education, Recreation \& Dance, Vol. 82, No. 8, 24-30.

Daesang, K. (2013). Student's Perception and Experiences of Mobile Learning.

Language Learning and Technology Journals, Vol. 17, No. 3, 52-73.

Depdiknas. (2008). Panduan Pengembangan Bahan Ajar. Direktorat Pembinaan Sekolah Menengah Atas. Departemen Pendidikan Nasional.

El-Hussein, M. O. M. (2010). Defining Mobile Learning in The Higher Education Landscape. Educational Technology \& Society Journal, Vol.13, No. 3, 12-21.

Gartner. (2013). Gartner Says Worldwide Traditional PC, Tablet, Ultramobile and Mobile Phone Shipments On Pace to Grow 7.6 Percent in 2014. Retrieved Maret 4, 2014, from http://www.gartner.com/news room/id/2645115.

Harfianti, R. (2010). Membangun Aplikasi Kamus Digital. Jombang: Lintas Media.

Istiqomah, A. (2006). Studi Digital Tree dan Aplikasinya pada Kamus. Retrieved November 24, 2013, from http://informatika.stei.itb.ac.i d/rinaldi.munir/Matdis/20062007/Makalah/Makalah060762.pdf.

Kasno. (2001). Kamus sebagai Sumber Rujukan dalam Pengakaran Kosakata. Makalah disajikan dalam 
KIPBIPA IV. Denpasar, Bali, Tanggal 1-3 Oktober 2001.

Lew, R. (2010). Multimodal Lexicography: The Representation of Meaning in Electronic Dictionaries. Lexikos 20 (AFRILEXreeks/series 20: 2010).

Mutiawani, V. (2011). Aplikasi Kamus Dwi Bahasa AvehIndonesia Berbasis Java untuk Telepon Genggam. Aceh: Informatika Unsyiah.

Nielsen. (2012). Nielsen Top of 2012 Digital. Retrieved Juli, 2014 from

http://www.nielsen.com/us/en /insights/news/2012/nielsentops-of-2012-digital.

Nugroho, A. (2004). Pemrograman Berorientasikan Objek. Yogyakarta: Andi.

Phillippi, J. C \& Wyatt, T. H. (2011). Smartphone in Nursing Education. CIN: Computers, Informatics, Nursing. Vol. 29, No. 8, 449-454.
Ratna, N. K. (2013). Glosarium: 1.250 Entri Kajian Sastra, Seni dan Sosial Budaya. Yogyakarta: Pustaka Pelajar.

Safaat, N. (2011). Pemrograman Aplikasi Mobile Smartphone dan Tablet PC Berbasis Android. Bandung: Informatika.

Sanjaya, W. (2011). Perencanaan dan Desain Sistem Pembelajaran. Jakarta: Prenada Media.

Silberschatz, A., Galvin, P., \& Gagne, G. (2005). Operating Systems Concepts. Seventh Edition. New Jersey: John Wiley \& Sons.

Suprawoto. (2009). Mengembangkan Bahan Ajar dengan Menyusun Modul. Retrieved Juni 27, 2014, from http://www.scribd.com/doc/1 6554502/MengembangkanBahan-Ajar-denganMenyusun-Modul. 